\title{
Mesoscale distribution of dominant bacterioplankton groups in the northern North Sea in early summer
}

\author{
Mikhail V. Zubkov ${ }^{1, *}$, Bernhard M. Fuchs ${ }^{2}$, Glen A. Tarran ${ }^{1}$, Peter H. Burkill ${ }^{3}$, \\ Rudolf Amann ${ }^{2}$
}

\author{
${ }^{1}$ Plymouth Marine Laboratory, Prospect Place, Plymouth PL1 3DH, United Kingdom \\ ${ }^{2}$ Max-Planck-Institute for Marine Microbiology, Celsiusstrasse 1, 28359 Bremen, Germany \\ ${ }^{3}$ Southampton Oceanography Centre, Southampton SO14 3ZH, United Kingdom
}

\begin{abstract}
A case study was performed to evaluate the potential of a combination of flow cytometry, cell sorting and fluorescence in situ hybridisation (FISH) for mesoscale monitoring of dominant bacterioplankton groups. In June 1999, the spatial distribution of phylogenetically characterised bacterioplankton groups in an area of $150 \times 350 \mathrm{~km}$ in the northern North Sea was studied in conjunction with blooms of phytoplankton including coccolithophores. The bacterial cells were enumerated using flow cytometry and 3 groups were defined on the basis of cellular light scatter, nucleic acid and protein content. The phylogenetic composition of cells sorted from those 3 groups was analysed using FISH with a restricted set of rRNA targeted oligonucleotide probes. Cells with high nucleic acid and high protein content were mainly affiliated to the $\alpha$-proteobacterial genus Roseobacter. Members of the Cytophaga-Flavobacterium cluster consistently accounted for the majority of cells in the high nucleic acid and low protein group; and members of the $\gamma$-proteobacterial SAR86 cluster were always present in significant amounts among the cells with low nucleic acid and low protein content. The composition of bacteria within the groups was remarkably conservative in 13 randomly selected samples, while the concentration of the groups varied considerably on the 10 to $100 \mathrm{~km}$ scale. The bacterial groups formed patches of high abundance; these were spatially separated and could remain traceable for 2 to $3 \mathrm{~d}$. The distribution of bacterioplankton groups did not correlate with distribution of either chlorophyll a (chl a), or phytoplankton groups (small coccolithophores and picoeukaryotic algae) or physical parameters such as temperature and salinity. It seems unlikely therefore that currently used remotely sensed parameters may be used as proxies of bacterioplankton group concentration at basin scales. However, this case study proves that a shipboard survey conducted over 4 to $6 \mathrm{~d}$ is effective for identifying and monitoring patches of certain bacterioplankton groups.
\end{abstract}

KEY WORDS: Community composition · Diversity · Patchiness · FISH $\cdot$ Flow cytometry · Marine bacteria $\cdot$ North Sea

Resale or republication not permitted without written consent of the publisher

\section{INTRODUCTION}

The individual members of the heterotrophic bacterioplankton are key catalysts of the biogeochemical cycles of nutrients in the sea through their decomposition of organic matter (Pomeroy 1974, Azam et al. 1983). Although the patterns of abundance of bacteria

${ }^{*}$ Present address: Southampton Oceanography Centre, Southampton SO14 3ZH, United Kingdom.

E-mail: mvz@soc.soton.ac.uk in the sea are generally known, we remain ignorant of the importance of many of the different bacterial species. This is because of the difficulty of identification and monitoring of bacterial species based on cell morphology or cultivation. As a result bacterioplankton has often been described as a 'black-box' community. Recently, strong support for significant bacterioplankton diversity came with the introduction of ribosomal RNA gene sequencing as a tool in bacterial systematics (Woese 1987) and its subsequent application to marine environments (Giovannoni \& Rappe 2000 and refer- 
ences therein). The biogeochemical implications of the phylogenetic diversity of marine microbial communities are poorly understood, but indirect evidence suggests that enzymatic processing of organic matter can change due to shifts in bacterioplankton composition (Riemann et al. 1999 and references therein). Thus, quantitative monitoring of phylogenetically characterised bacterioplankton, and revealing spatial and temporal compositional shifts may prove to be important for understanding the more subtle roles of bacterioplankton in marine biogeochemistry.

Our understanding of high-resolution spatial variability in marine bacterial communities is still rudimentary. It has been suggested that marine bacteria aggregate into small-scale patches or 'hot spots' (Azam 1998) in response to favourable environmental conditions. Such conditions may occur around dissolved organic matter diffusing from phytoplankton cells (Mitchell et al. 1985, Bowen et al. 1993), organic particles (Shanks \& Trent 1979, Alldredge \& Cohen 1987), and discrete nutrient patches (Lehman \& Scavia 1982, Blackburn et al. 1997, 1998). Nevertheless, there was no direct evidence of $\mu \mathrm{m}$ scale (10 to $100 \mu \mathrm{m}$ ) bacterial heterogeneity in association to algal cells (MullerNiklas et al. 1996). Spatial heterogeneity in bacterioplankton abundance has been observed at the $\mathrm{mm}$ (Seymour et al. 2000, Long \& Azam 2001) and cm (Mitchell \& Fuhrman 1989, Duarte \& Vaque 1992) scales within a continuously variable distribution of bacterioplankton at a larger scale. On a m scale, variability has been usually associated with studies of bacterioplankton vertical distribution in a water column (Ducklow 2000 and references therein). Macroscale spatial variability of bacterioplankton (i.e. from crossfrontal to basin scales) has been mostly studied using a transect approach (e.g. Zubkov et al. 2000a, Brown \& Landry 2001). However, insufficient knowledge about spatial distribution of dominant bacterial groups at a multi-km scale (10 to $100 \mathrm{~km}$ ) critically limits evaluation of scales of biogeochemical processes driven by marine bacterioplankton.

Supported by the mesoscale hydrographic structures, patches dominated by phytoplankton and bacterioplankton were observed simultaneously (Karrasch et al. 1996). The spatial and temporal intermittency of turbulent stirring generates such patchiness (Abraham 1998) and poses a complex sampling problem. Adequate resolution requires series of physical, chemical and micro- biologicial measurements to be made at the same scale, which is, due to time-consuming procedures, most difficult for the biological component. We performed a mesoscale bacterioplankton study combining the speed and accuracy of flow cytometry with the precision of cell sorting and molecular identification by fluorescence in situ hybridisation (FISH) with rRNAtargeted oligonucleotide probes.

In the present study, we investigate the suitability of the recently developed methodology (Fuchs et al. 2000b, Zubkov et al. 2001a) for mesoscale monitoring of taxonomically defined bacterioplankton groups. We make no pretensions that the probe set applied here is all encompassing; rather, we were interested in finding out whether our approach is suitable for obtaining evidence of patchy distribution of dominant bacterial groups.

\section{MATERIALS AND METHODS}

Sampling site. Using satellite colour imagery and high reflectance from the coccoliths of Emiliania huxleyi, a phytoplankton bloom that covered an area of approximately $2000 \mathrm{~km}^{2}$ was located in the northern part of the North Sea. A survey on board the RRS 'Discovery' (Cruise 241) was carried out in the northern proximity of the bloom in the area 56.5 to $61^{\circ} \mathrm{N}$ and $2^{\circ} \mathrm{W}$ to $3.5^{\circ} \mathrm{E}$ in June 1999 . Most of the area was surveyed over $5 \mathrm{~d}$ on a course shown in Fig. 1. Tempera-

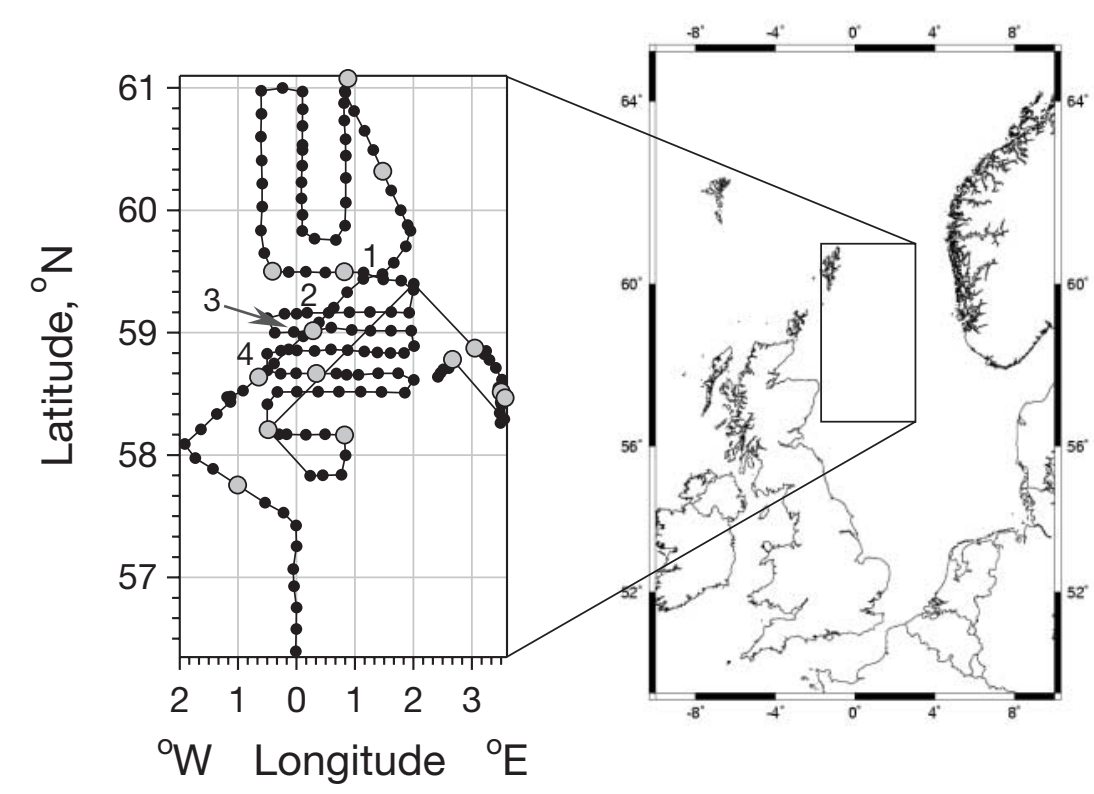

Fig. 1. Study area and ship's track during the survey. Small dots indicate underway samples and larger grey open dots indicate samples which were analysed for bacterioplankton composition using FISH. Numbers indicate places revisited during the survey (see details in the text) 
ture, salinity and chlorophyll a ( $\mathrm{chl}$ a) fluorescence were recorded every minute. A total of 134 samples of bacterioplankton and phytoplankton were collected at hourly intervals, using the ship's underway non-toxic supply system and an additional 23 surface water samples were collected during the subsequent Lagrangian study (Zubkov et al. 2001a). Flow cytometry was employed for enumerating 3 main groups of bacterioplankton as well as eukaryotic picophytoplankton and coccolithophores.

Flow cytometry. Abundance of selected phytoplanktonic groups was determined in freshly collected unfixed samples using a FACSort flow cytometer (Becton Dickinson) as described previously (Tarran et al. 2001). Bacterioplankton was fixed with $1 \%$ paraformaldehyde (PFA), stained with SYBR Green I DNA dye (Marie et al. 1997, Zubkov et al. 2000b) and initially enumerated on board the ship using the same instrument. The samples fixed with $1 \%$ PFA at $2^{\circ} \mathrm{C}$ for $24 \mathrm{~h}$ were stored frozen at $-20^{\circ} \mathrm{C}$. On the return from the cruise bacterial group biomass was estimated after DNA/protein double staining with Hoechst 33342 and SYPRO Red dyes using a FACStar Plus flow cytometer (Becton Dickinson) as described previously (Zubkov et al. 1999). The SYPRO-protein cell fluorescence was calibrated using 4 bacterial cultures. The protein biomass of the latter was directly measured using the bicinchoninic acid method (BCA-1 kit, Sigma). Yellowgreen micro-spheres of $0.5 \mu \mathrm{m}$ diameter (Fluoresbrite Microparticles; Polysciences) were used as an internal standard to normalise among samples and to calculate bacterial protein content. The absolute concentration of beads in a standard stock suspension was determined by flow cytometric counting of beads in volumes dispensed with an automatic micro-injector (KD Scientific). The ratio of bead abundance to that of bacteria was used to compute the absolute concentration of the latter. Bacterial biomass was calculated by multiplying bacterial abundance by mean protein content of bacterial cells. The protein content of bacteria was assumed to be equal to carbon cellular content (Simon \& Azam 1989).

FISH. Thirteen randomly selected bacterioplankton samples were used for cell sorting (Fig. 1). Bacterial cells, sorted from 3 main flow cytometric groups, were collected on polycarbonate filters $(0.2 \mu \mathrm{m}$ pore size) for FISH analysis (Glockner et al. 1996, Fuchs et al. 2000b). The sorted cells were hybridised with a set of probes: GMP1242, specific for the $\gamma$-proteobacterial SAR86 cluster (Mullins et al. 1995) is 5' AGCGTCCGTCTGTATCTC 3'; RSB67, specific for the $\gamma$-proteobacterial genus Roseobacter is 5' CGCTCCACCCGAAGGTAG 3' (Zubkov et al. 2001a); CF319a, specific for Cytophaga-Flavobacterium cluster (Manz et al. 1996); ALF968, specific for the $\alpha$-subclass of Pro- teobacteria, GAM42a, specific for $\gamma$-subclass of Proteobacteria and EUB338, specific for Bacteria (Amann et al. 1990). Probes labelled with fluorescence indocarbocyanine dye CY3 and unlabelled helper oligonucleotides (Fuchs et al. 2000a) were synthesised commercially (Interactiva). Cells were viewed using an Axioscop 2 epifluorescence microscope equipped with a $100 \times$ plan neofluar objective (Zeiss) and at least 300 were counted per sorted sample. Probe positive cells were presented as percentages of cells stained with a general nucleic acid dye, 4,6-diamidino-2-phenylindole (DAPI). To estimate absolute concentrations of each bacterial group, the percentages were multiplied by the total bacterial concentration determined by flow cytometry.

Data analysis. Acquisition and preliminary analysis of flow cytometric data were done using CellQuest software (Becton Dickinson). Correlation, regression analyses and $t$-test were used for comparison of the data sets.

\section{RESULTS}

\section{Phylogenetic affiliation of flow cytometric bacterioplankton groups}

The composition of the bacterioplankton community was flow cytometrically characterised on the basis of protein and nucleic acid content of individual cells. Three main groups were clearly seen on density plots of all samples analysed: cells with high nucleic acid content and high protein content (HNA-hp group), cells with high nucleic acid content and low protein content (HNA-lp group), and cells with low nucleic acid content (LNA group) (Fig. 2). The 2 HNA groups could only be clearly discriminated using their protein content (Fig. 2b,c); the complex nature of light scattering by bacterial cells in the forward direction did not allow their clear separation (Fig. 2a). The differences of cellular DNA and protein contents between the groups were greater than variation introduced by cell growth. Using CellQuest software, the polygons were drawn by eye to enumerate cells and to sort cells from the 3 groups (Fig. 2).

The samples were adequately preserved for compositional analyses, but some loss of bacterial cells occurred as a result of sample storage. Comparison of bacterioplankton counts, done on board the ship and ashore, revealed that $79 \%$ (regression coefficient $\mathrm{r}^{2}=$ $0.91, \mathrm{n}=120, \mathrm{p}<0.0001$ ) of all bacterioplankton cells and $78 \%\left(r^{2}=0.85, n=120, p<0.0001\right)$ of cells from the LNA group were accounted for in the stored frozen samples. There is no ideal method of bacterioplankton sample preservation and some loss of cells was un- 


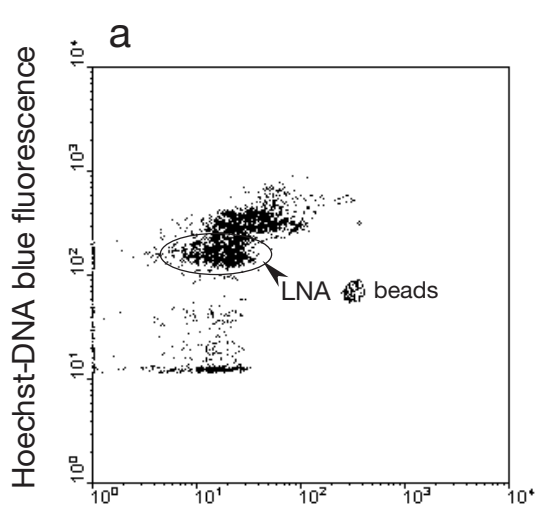

Forward light scatter

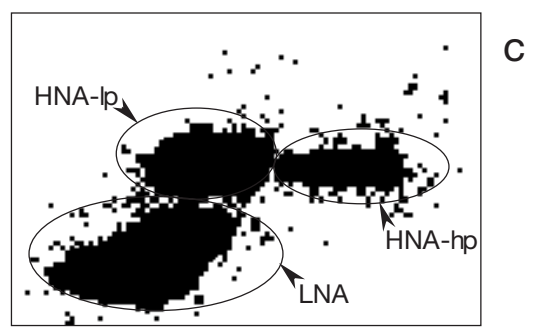

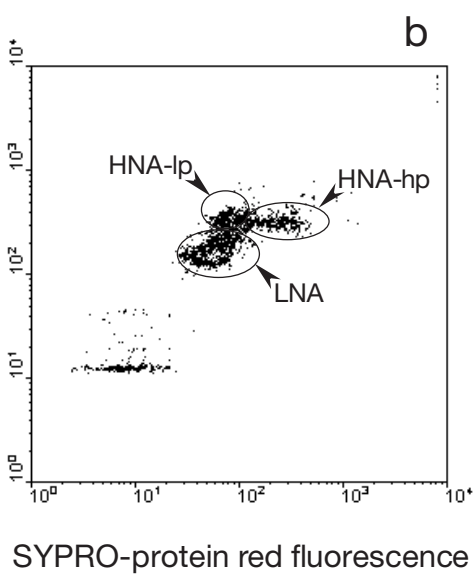

Fig. 2. A representative flow cytometric signature of bacterioplankton dual stained for DNA and protein showing 3 discriminated groups indicated by ovals and arrows. Density plots of (a) light forward scatter versus particle DNA fluorescence and (b) particle protein versus DNA fluorescence. (c) Enlargement of bacterioplankton signature from (b) as a dot plot

Table 1. Results of FISH with cells flow sorted from 3 main flow cytometric groups. Values are percentages probe positive cells detectable after counter staining with DAPI. Numbers in brackets (n) are numbers of analysed samples (see probe description in the text). ${ }^{*}$ Sum of percentages of cells detected with probes specific to different phylogenetic clusters

\begin{tabular}{|c|c|c|c|c|c|c|}
\hline \multirow[t]{2}{*}{ Probe } & \multicolumn{2}{|c|}{ HNA-hp group } & \multicolumn{2}{|c|}{ HNA-lp group } & \multicolumn{2}{|c|}{ LNA group } \\
\hline & Mean $\pm \mathrm{SD}$ & $\mathrm{n}$ & Mean \pm SD & $\mathrm{n}$ & Mean \pm SD & $\mathrm{n}$ \\
\hline EUB338 & $94 \pm 4$ & (11) & $90 \pm 11$ & (10) & $81 \pm 13$ & (6) \\
\hline Sum* & $84 \pm 11$ & (13) & $84 \pm 11$ & (11) & $26 \pm 22$ & (7) \\
\hline ALF968 & $57 \pm 16$ & (13) & $9 \pm 9$ & (11) & $4 \pm 5$ & (5) \\
\hline RSB67 & $57 \pm 17$ & (15) & $4 \pm 4$ & (8) & $1 \pm 0.4$ & (7) \\
\hline GAM42a & $15 \pm 9$ & (12) & $2 \pm 2$ & (11) & $2 \pm 2$ & (5) \\
\hline CF319a & $10 \pm 5$ & (7) & $63 \pm 15$ & (11) & $4 \pm 7$ & (7) \\
\hline SAR86/1242 & $0.5 \pm 0.7$ & $(7)$ & $6 \pm 5$ & (7) & $16 \pm 17$ & (8) \\
\hline
\end{tabular}

avoidable. However, similar percentages of the total bacterioplankton and LNA group indicated that selective loss of bacterioplankton groups was unlikely. Therefore, one could conclude that the composition of bacterioplankton in frozen samples was representative of natural composition.

We hypothesised that phylogenetic composition of each of the flow cytometric groups remained similar in the studied area. To test this hypothesis, cells from each of the groups were flow sorted from 13 randomly selected samples (Fig. 1, large dots). The sorted cells were phylogenetically affiliated using FISH (Table 1). According to FISH, bacteria dominated all samples, between 81 and $94 \%$ of the cells hybridised with a general bacterial probe, EUB338. Therefore, the concentration of Archaea in the surface waters surveyed in this study was likely to be low. It was evident that members of the genus Roseobacter accounted for almost all $\gamma$ proteobacteria and the HNA-hp group was predominantly of this genus. Only about $10 \%$ of cells in the HNA-hp group belonged to the $\mathrm{CF}$ cluster and $15 \%$ belonged to the $\gamma$-proteobacteria. On average, bacteria of the CF cluster comprised $63 \%$ of sorted cells from the HNA-lp group, and only $9 \%$ of cells belonged to the $\alpha$-proteobacteria and $6 \%$ of cells were from the SAR86 cluster. The majority of cells from the LNA group were also bacteria, $81 \%$ of the sorted cells hybridised with the general bacterial probe. On average, $16 \%$ of cells hybridised with a probe specific to the SAR86 cluster (GMP1242), and an even smaller percentage was detected with other specific probes used. A more precise identification of the remaining cells was not possible with the probe set applied in this study.

The flow cytometric groups of bacterioplankton obviously represented quite stable assemblages of defined taxonomic groups that were relatively similar in different parts of the studied area (Table 1). This compositional constancy was most pronounced in the HNA-hp group dominated by the Roseobacter-related $\alpha$-proteobacteria. The probe CF319a, which consistently hybridised to the majority of cells in the HNA-lp flow cytometric group, targeted a fairly large taxonomic group and, therefore, we cannot rule out substantial spatial variation within this group. The same is true for the LNA group, in which roughly 1 out of 6 cells could be assigned to the SAR86 cluster.

The cells from the HNA-hp group containing $30 \pm 8.5$ fg protein cell ${ }^{-1}(\mathrm{n}=157)$ were 3 times richer in protein than the cells in the HNA-lp group $(10 \pm 2 \mathrm{fg}$ protein cell ${ }^{-1}$ ), and 5 times richer than the cells in the LNA group $\left(6 \pm 1.3 \mathrm{fg}\right.$ protein cell $\left.^{-1}\right)$. Therefore, although the LNA group often dominated bacterial numbers, the HNA-hp usually dominated bacterioplankton biomass. Interestingly, a significant negative correlation was revealed between the fractions of the HNA-hp and LNA groups (Fig. 3), whereas no correlation was found between the fractions of the LNA and 


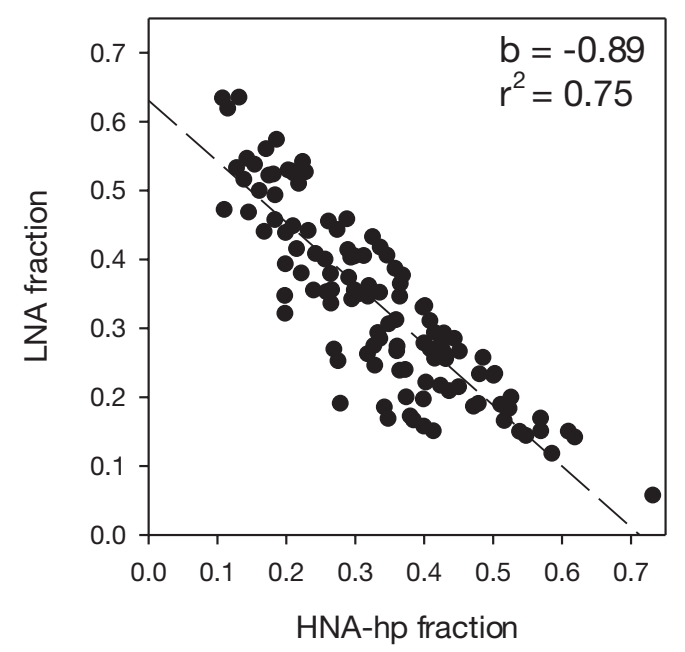

Fig. 3. Relationship between fractions of the HNA-hp and LNA groups within the bacterioplankton community in the surveyed area. A dashed line shows linear regression with corresponding slope $b$ and regression coefficient $r^{2}$

HNA-lp groups. To identify possible relationships between bacterioplankton groups as well as phytoplankton and physical parameters, paired correlation coefficients were computed for all parameters measured and more significant coefficients between bacterioplankton groups were summarised in Table 2 . Abundance of the HNA-lp and LNA groups correlated strongly with total bacterioplankton concentration, and biomass of both HNA-hp and HNA-lp groups correlated with total biomass, but no statistically significant correlation was found between bacterioplankton groups and either phytoplankton or physical parameters. Seeking an explanation, we compared patterns of spatial distribution.

Table 2. Correlation between concentrations of 3 bacterioplankton groups in the surveyed area. To assist reading the table coefficients of correlation higher than 0.8 are marked in bold

\begin{tabular}{|lccccccc|}
\hline \multicolumn{7}{c|}{ Bacterioplankton group } \\
Variables & $\begin{array}{c}\text { HNA- } \\
\text { hp }\end{array}$ & $\begin{array}{c}\text { HNA- LNA } \\
\text { lp }\end{array}$ & & & Total & HNA- HNA- \\
hp & lp & \\
\hline Numbers & & & & & & & \\
HNA-hp & 1 & & & & & & \\
HNA-lp & 0.57 & 1 & & & & & \\
LNA & 0.34 & 0.77 & 1 & & & & \\
Total & 0.59 & $\mathbf{0 . 9 3}$ & $\mathbf{0 . 9 3}$ & 1 & & & \\
Biomass & & & & & & & \\
HNA-hp & $\mathbf{0 . 8 5}$ & 0.57 & 0.37 & 0.60 & 1 & & \\
HNA-lp & 0.63 & $\mathbf{0 . 9 5}$ & 0.64 & $\mathbf{0 . 8 4}$ & 0.63 & 1 & \\
LNA & 0.36 & 0.76 & $\mathbf{0 . 9 8}$ & $\mathbf{0 . 9 2}$ & 0.39 & 0.67 & 1 \\
Total & $\mathbf{0 . 8 0}$ & $\mathbf{0 . 8 4}$ & 0.67 & $\mathbf{0 . 8 6}$ & $\mathbf{0 . 9 0}$ & $\mathbf{0 . 8 6}$ & 0.69 \\
\hline
\end{tabular}

\section{Spatial distribution of bacterio-, phytoplankton and physical properties of seawater}

Spatial distribution of the 3 groups in the surveyed area was mapped using contour plots (Fig. 4). Distributions of the HNA groups were generally similar with the highest concentrations in the north-central part of the area. The LNA group showed a distinctly different distribution to the other 2 groups with the highest concentrations to the south-west. The group biomass fields were similar to number distribution patterns (Fig. 4, right column). Spatial distributions of the other parameters in the surveyed area were contour plotted using the same algorithm (Fig. 5). Surface waters in the north-east were about $1^{\circ} \mathrm{C}$ higher than waters that had intruded from the west (Fig. 5a). While salinity gradually decreased by about 0.25 ppt in a south-easterly direction (Fig. 5b), these bore little similarity to the distributions of bacteria. Consequently, more dense surface water protruded from the west towards the middle of the area (Fig. 5c).

Three phytoplankton parameters were selected for comparison with bacteria. Fluorescence of chl a was used as an index of total phytoplankton biomass. Satellite images of light backscatter revealed a developing bloom of coccolithophore algae in the area and therefore, monitoring small coccolithophores was used to verify remote sensing data. High abundance of picoeukaryotic algae are usually characteristic of either very early or late stages of phytoplankton blooms (M.V.Z. pers. obs.), and picoeukaryotic algae were used as an index of such stages of community development. The highest concentration of chl a was restricted to the northern part of the area (Fig. 5d). The lowest concentration of chl a was in the south-eastern part of the area where the highest concentration of small coccolithophores was determined (Fig. 5e). Spatial distribution of the coccolithophores in all respects differed from the distribution of picophytoplankton (Fig. 5f). The highest concentration of the latter was observed in the northern and south-western parts of the area and the lowest concentration was in the middle of the area.

\section{Identification and comparison of planktonic patches}

We evaluated the statistical significance of observed spatial heterogeneity. Guided by the contour plots, 3 distinct regions enriched with one of the groups of bacterio- or phytoplankton were identified. The contour of the HNA-hp biomass of $7 \mu \mathrm{C} \mathrm{C}^{-1}$ was chosen as a boundary of the first region, R1, the contour of the LNA bio- 


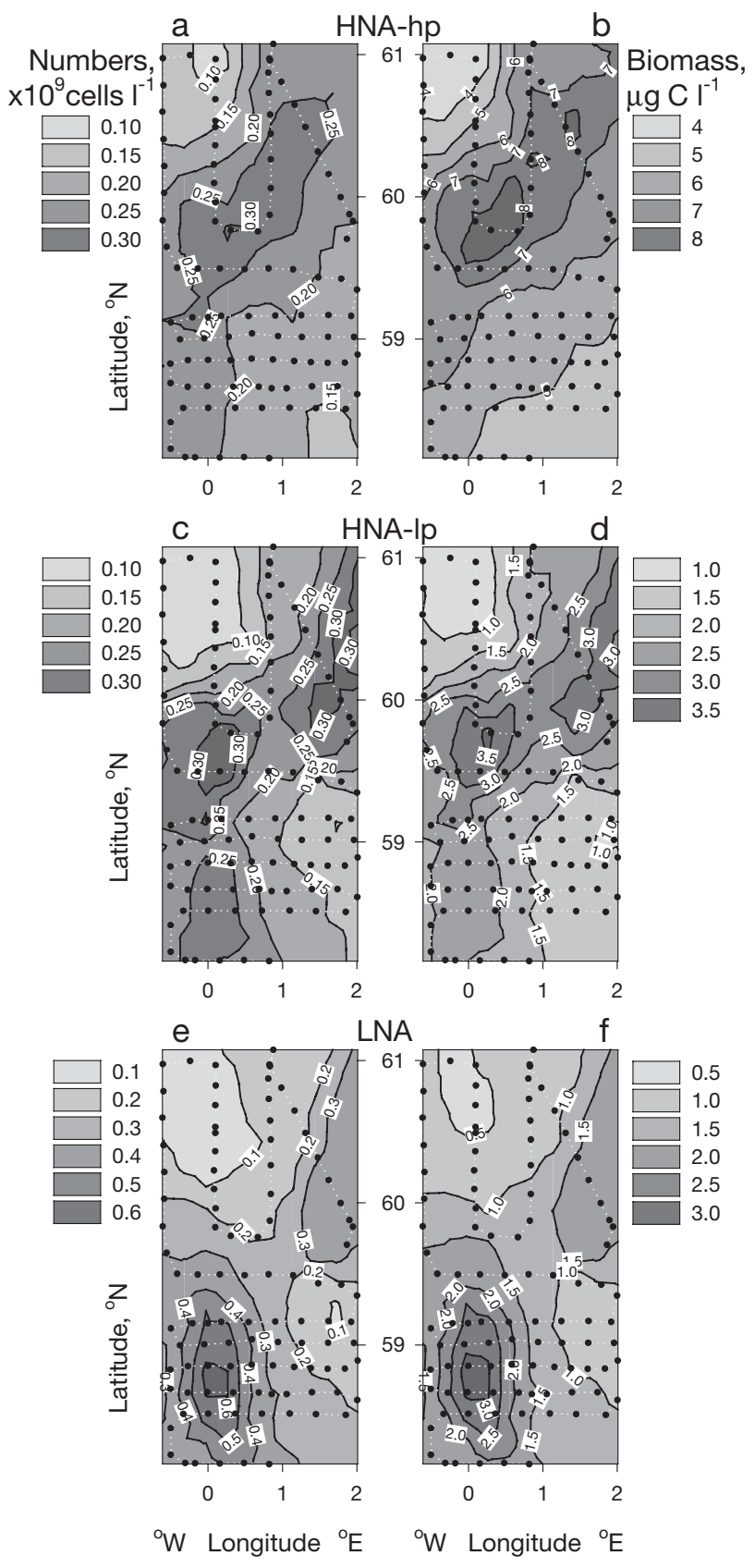

Fig. 4. Spatial distribution of abundance (left column) and biomass (right column) of 3 bacterioplankton groups. Dots indicate underway sampling points, contours were calculated using a running average of $10 \%$ of a data set

mass of $2 \mu \mathrm{g} \mathrm{C}^{-1}$ as a boundary for the second region, $\mathrm{R} 2$, and the contour of the coccolithophore abundance of $0.35 \times 10^{6}$ cells $\mathrm{l}^{-1}$ as a boundary for the third region, R3. The sampling points within those contours were considered to represent the corresponding regions. The sample sets of measured parameters that characterised the 3 regions were compared using the $t$-test (Table 3).
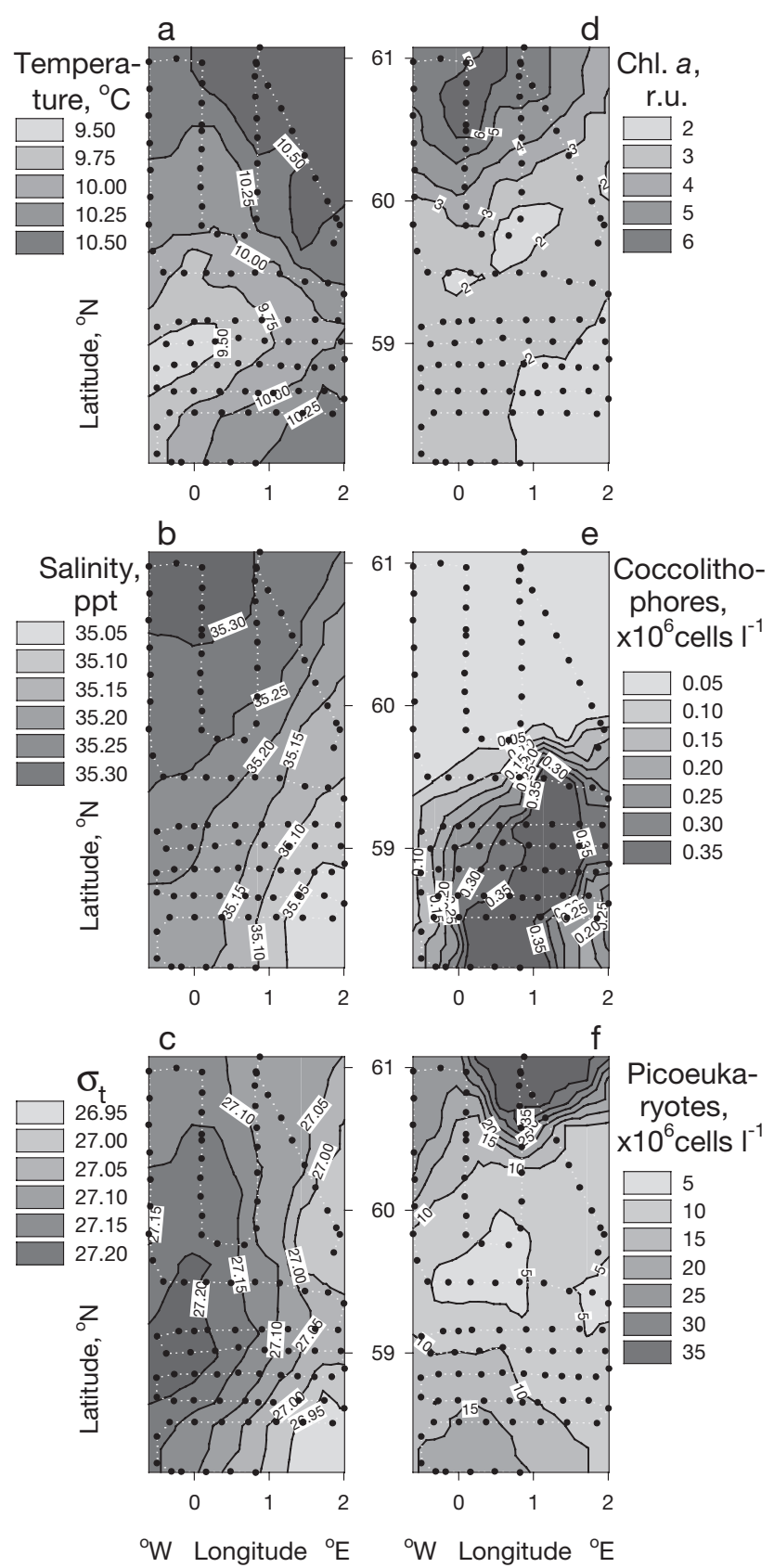

Fig. 5. Spatial distribution of (a) temperature, (b) salinity, (c) calculated water density, $\sigma_{\mathrm{t}}$ (d) chl a, (e) abundance of coccolithophores and (f) picoeukaryotic algae in the surveyed area. Dots indicate underway sampling points, contours were calculated similar to Fig. 4

According to the $t$-test, the numbers and biomass of the HNA-hp group were both significantly higher in R1 than in the other 2 regions, and the LNA group concentration was the highest in R2. However, the numbers of total bacterioplankton were similar in the 2 regions and total biomass was only slightly higher in R1. Regarding the phytoplankton, the concentrations of chl $a$ and picophytoplankton were similar, while R2 
Table 3. Comparison of bacterioplankton, phytoplankton and physical parameters in 3 identified regions using the $t$-test. Probability symbols: $(=)$ difference between 2 values is insignificant $(\mathrm{p}>0.05) ;\left(^{*}\right)$ is significant $(\mathrm{p}<0.05)$. Density $\left(\mathrm{kg} \mathrm{l}^{-1}\right)=1+\sigma_{\mathrm{t}} / 10^{3}$; $\mathrm{n}$ : number of samples collected within identified region (see Figs. 4 \& 5)

\begin{tabular}{|c|c|c|c|c|c|c|c|}
\hline \multirow[t]{4}{*}{ Parameter } & \multirow[t]{4}{*}{ Units } & \multicolumn{3}{|c|}{ R1 } & \multicolumn{2}{|l|}{ R2 } & R3 \\
\hline & & R1 & vs & R2 & vs & R3 & vs \\
\hline & & $(\mathrm{n}=16)$ & R2 & $(\mathrm{n}=17)$ & R3 & $(\mathrm{n}=22)$ & R1 \\
\hline & & Mean \pm SD & $t$ & Mean \pm SD & $t$ & Mean \pm SD & $t$ \\
\hline \multicolumn{8}{|l|}{ Bacterioplankton } \\
\hline \multicolumn{8}{|l|}{ Numbers } \\
\hline HNA-hp group & $\times 10^{9}$ cells l $^{-1}$ & $0.30 \pm 0.10$ & * & $0.22 \pm 0.05$ & * & $0.18 \pm 0.04$ & ${ }^{*}$ \\
\hline HNA-lp group & $\times 10^{9}{\text { cells } 1^{-1}}^{-1}$ & $0.29 \pm 0.21$ & $=$ & $0.23 \pm 0.08$ & * & $0.17 \pm 0.08$ & * \\
\hline LNA group & $\times 10^{9}$ cells $^{-1}$ & $0.20 \pm 0.18$ & $*$ & $0.51 \pm 0.31$ & * & $0.24 \pm 0.18$ & $=$ \\
\hline Total & $\times 10^{9}{\text { cells } 1^{-1}}^{-1}$ & $0.84 \pm 0.46$ & $=$ & $1.01 \pm 0.40$ & $*$ & $0.63 \pm 0.26$ & $=$ \\
\hline \multicolumn{8}{|l|}{ Biomass } \\
\hline HNA-hp group & $\mu \mathrm{g} \mathrm{C} 1^{-1}$ & $8.4 \pm 2.1$ & * & $5.7 \pm 1.1$ & * & $5.0 \pm 1.0$ & * \\
\hline HNA-lp group & $\mu g \mathrm{C}^{-1}$ & $3.2 \pm 1.8$ & $*$ & $2.1 \pm 0.7$ & * & $1.4 \pm 0.5$ & * \\
\hline LNA group & $\mu g \mathrm{C}^{-1}$ & $1.3 \pm 0.7$ & $*$ & $2.6 \pm 1.7$ & * & $1.2 \pm 0.8$ & $=$ \\
\hline Total & $\mu \mathrm{g} \mathrm{C} 1^{-1}$ & $13.8 \pm 4.3$ & * & $11.1 \pm 2.7$ & * & $8.2 \pm 1.6$ & * \\
\hline \multicolumn{8}{|l|}{ Phytoplankton } \\
\hline Chl a & r.u. & $2.6 \pm 1.9$ & $=$ & $2.3 \pm 0.5$ & $=$ & $2.0 \pm 0.6$ & $=$ \\
\hline Coccolithophores & $\times 10^{6}$ cells $^{-1}$ & $0.03 \pm 0.05$ & * & $0.25 \pm 0.20$ & * & $0.48 \pm 0.38$ & * \\
\hline Picoeukaryotes & $\times 10^{6}{\text { cells } 1^{-1}}^{-1}$ & $5.60 \pm 5.13$ & $=$ & $9.96 \pm 7.78$ & $=$ & $11.36 \pm 9.89$ & * \\
\hline Temperature & ${ }^{\circ} \mathrm{C}$ & $10.2 \pm 0.5$ & * & $9.5 \pm 0.3$ & ${ }^{*}$ & $10.0 \pm 0.5$ & $=$ \\
\hline Salinity & ppt & $35.26 \pm 0.03$ & * & $35.19 \pm 0.03$ & * & $35.10 \pm 0.06$ & * \\
\hline Density & $\sigma_{\mathrm{t}}$ & $27.14 \pm 0.09$ & * & $27.20 \pm 0.06$ & * & $27.04 \pm 0.11$ & * \\
\hline
\end{tabular}

was significantly enriched in coccolithophores compared to R1. R1 and R2 seemed to be in different water masses; both temperature and salinity was significantly higher in R1 than in R2.

R3 was also in different waters of significantly lower salinity than waters of the other 2 regions. Despite the concentration of chl a being similar in the 3 regions, the highest coccolithophore concentrations were found in R3. The bacterioplankton concentrations of all groups were significantly lower in R3 than in R2, and the HNA-hp concentration was significantly lower in R3 than in R1.

Thus, the 3 regions identified within the area studied were indeed significantly different according to most parameters measured. The group composition of bacterioplankton was also different. The HNA-hp group constituted $40 \pm 12 \%$ of bacterioplankton cells in R1, and significantly less, only $24 \pm 9 \%$, in R2. Conversely the LNA group constituted $23 \pm 8 \%$ in R1, and a significantly higher percentage, $48 \pm 11 \%$, in R2.

\section{Estimation of temporal changes of measured parameters}

A complication of the spatial survey was its duration, as it took $5.7 \mathrm{~d}$ to complete (Fig. 1). The diagonal from the south-west $\left(58^{\circ} \mathrm{N}, 2^{\circ} \mathrm{W}\right)$ to north-east $\left(59^{\circ} 45^{\prime} \mathrm{N}\right.$, $2^{\circ} \mathrm{E}$ ) gave an opportunity to observe temporal changes between the first and subsequent passages through 4 selected geographical places where the survey track crossed the diagonal (Fig. 1). Surprisingly, this showed little significant temporal change of salinity, both phytoplankton groups and bacterioplankton. Only the variations of the HNA-lp concentration were statistically significant (results of computation are not shown). However, although salinity remained unchanged, there was a significant $1.4^{\circ} \mathrm{C}$ decrease in water temperature. The latter could be the result of cold water intrusion from the west than direct water cooling. To minimise temporal distortions of spatial distribution revealed on the contour plots, we only used the 101 samples of the box survey that took only $4.25 \mathrm{~d}$ to complete (Figs. 4 \& 5).

\section{DISCUSSION}

Although there is a well established understanding of the key role of heterotrophic bacterioplankton in the mineralisation of dissolved organic matter in the sea (Azam et al. 1983), information on the taxonomic composition of bacterioplankton communities associated with phytoplankton blooms is rather limited (Gordon \& Giovannoni 1996, Kerkhof et al. 1999, Riemann et al. 1999, Simon et al. 1999, Gonzalez et al. 2000). In the present study, we employed a recently developed technique that combined flow sorting of bacteria from a main cytometric group and their FISH identification (Zubkov et al. 2001a). The approach couples the preci- 
sion of phylogenetic identification based on rRNAtargeted oligonucleotide probes with the analytical precision of flow cytometric counting of bacterial cells. In the short time and restricted area investigated, the taxonomic composition of 3 flow cytometric groups distinguished by their different DNA and protein contents was quite stable, at least within the relatively coarse resolution of the probe set applied. Successful application of the Roseobacter-specific probe RSB67 for identification of dominant bacterial population in the HNA-hp group showed the potential of developing more specific probes. Based on 16S rRNA, it is frequently possible to design specific probes down to the species level (Amann et al. 1995), and it was recently shown that even low and high light adapted 'ecotypes' of Prochlorococcus sp. can be distinguished using the 16S rRNA probes (West et al. 2001). However, one should not expect that all ecologically different species have different 16S rRNA sequences.

One of the interesting features of the monitoring of different bacterioplankton groups was a significant negative relationship between the Roseobacter-dominated HNA-hp and LNA group (Fig. 3). Previously, we had shown that cells from both of these 2 groups were metabolically highly active (Zubkov et al. 2001b). It is tempting to speculate that the observed relationship might reflect group competition for nutrients possibly produced by different phytoplankton assemblages. However, no relationship was found between bacterioplankton and phytoplankton groups. The HNA-hp and HNA-lp bacterial groups probably did not compete for the same DOM and therefore, their spatial distribution was similar. It is possible that the Roseobacter-related $\alpha$-proteobacteria in HNA-hp group were consuming the more labile fraction of DOM (Zubkov et al. 2001a), while the members of the Cytophaga-Flavobacterium cluster in the HNA-lp were specialised in breaking down macromolecules (Cottrell \& Kirchman 2000).

The spatial distribution of the bacterioplankton groups was found to be patchy. The patches were not only spatially separated (Fig. 4), but also did not match with the spatial distributions either of selected phytoplankton groups or of physical parameters (Fig. 5). The characteristic mesoscale spatial patterns of planktonic populations are a consequence of the timescales of their response to changes in their physical environment caused by turbulent advection (Abraham 1998). Because bacteria depend ultimately on phytogenic DOM, their response is temporally delayed relative to the phytoplankton, and this could lead to the spatial decoupling we report. Consequently, higher concentrations of the phytoplankton groups matched with lower concentrations of bacterioplankton groups as exhibited, for example, in R3 which was enriched with coccolithophores (Table 3). Similar patterns were observed previously and their origin was attributed to a mesoscale hydrographic variability (Karrasch et al. 1996). Many factors, such as origin of hydrographic structures, their specific physical parameters and history must be considered in order to explain and to understand their biological constitution at the moment of observation (Le Groupe Tourbillon 1983). However, in the present study hydrography could not provide a decisive explanation of observed bacterioplankton patchiness.

Satellite imagery has been the main route by which mesoscale variability of the sea surface has been studied (Garcon et al. 2001). The reason for comparing bacterioplankton group concentrations with phytoplankton and physical parameters was to search for possible relationships and if found, to use 1 parameter for predicting the distribution of another parameter. Unfortunately, unpigmented bacteria seem unlikely to be directly remotely sensed or approximated using other parameters. This makes the ability to determine their concentrations by ship survey, particularly important.

A limitation of a ship's spatial survey is its duration. It took $4.25 \mathrm{~d}$ to complete the box survey. However, the design of the survey (Fig. 1) allowed us to evaluate an effect of temporal changes on revealed spatial variability. It was interesting to observe that there were few significant changes in bacterioplankton and phytoplankton within 2 to $3 \mathrm{~d}$. Consequently, if a survey is done within a few days, it can be effectively used for selecting stations representing patches of a certain bacterioplankton as well as phytoplankton group. On the other hand, the observed patchiness of bacterioplankton distribution cautioned against arbitrary extrapolations based on measurements of stocks and fluxes done at chance stations. The degree to which stations are representative of an area can only be proved using a spatial survey similar to the one conducted in this study.

Thus, the present study showed the utility of coupling flow cytometry, cell sorting and FISH in surveying bacterioplankton to identify spatial patchiness of phylogenetically characterised groups. This approach can help future studies focused on either explaining the biological mechanism of patchiness or evaluating spatial magnitudes of biogechemical processes driven by different bacterioplankton groups.

Acknowledgements. We thank all scientists, officers and crew aboard the RRS 'Discovery' for assistance. This work forms part of the Dimethylsulfide Biogeochemistry within a Coccolithophore Bloom (DISCO) project and was supported by the Natural Environment Research Council (NERC), UK MOD Defence Evaluation Research Agency and Max Planck Society. It is also a contribution to the Plymouth Marine Laboratory core strategic research programmes Scaling Biodiversity and the Consequences of Change and Microbially Driven 
Biogeochemical Cycles (contribution no. 116). The research of M.V.Z. was supported by the NERC postdoctoral research fellowship (GT5/98/16/MSTB) and subsequent advanced research fellowship (NER/I/S/2000/00898).

\section{LITERATURE CITED}

Abraham ER (1998) The generation of plankton patchiness by turbulent stirring. Nature 391:577-580

Alldredge AL, Cohen Y (1987) Can microscale chemical patches persist in the sea -microelectrode study of marine snow, fecal pellets. Science 235:689-691

Amann RI, Krumholz L, Stahl DA (1990) Fluorescent-oligonucleotide probing of whole cells for determinative, phylogenetic, and environmental studies in microbiology. J Bacteriol 172:762-770

Amann RI, Ludwig W, Schleifer KH (1995) Phylogenetic identification and in situ detection of individual microbial cells without cultivation. Microbiol Rev 59:143-169

Azam F (1998) Microbial control of oceanic carbon flux - the plot thickens. Science 280:694-696

Azam F, Fenchel T, Field JG, Gray JS, Meyer-Reil LA, Thingstad F (1983) The ecological role of water-column microbes in the sea. Mar Ecol Prog Ser 10:257-263

Blackburn N, Azam F, Hagström ̊̊ (1997) Spatially explicit simulations of a microbial food web. Limnol Oceanogr 42:613-622

Blackburn N, Fenchel T, Mitchell J (1998) Microscale nutrient patches in planktonic habitats shown by chemotactic bacteria. Science 282:2254-2256

Bowen JD, Stolzenbach KD, Chisholm SW (1993) Simulating bacterial clustering around phytoplankton cells in a turbulent ocean. Limnol Oceanogr 38:36-51

Brown SL, Landry MR (2001) Mesoscale variability in biological community structure and biomass in the Antarctic Polar Front region at 170 degrees W during austral spring 1997. J Geophys Res Oceans 106:13917-13930

Cottrell MT, Kirchman DL (2000) Natural assemblages of marine proteobacteria and members of the CytophagaFlavobacter cluster consuming low- and high-molecularweight dissolved organic matter. Appl Environ Microbiol 66:1692-1697

Duarte CM, Vaque D (1992) Scale dependence of bacterioplankton patchiness. Mar Ecol Prog Ser 84:95-100

Ducklow H (2000) Bacterial production and biomass in the oceans. In: Kirchman D (ed) Microbial ecology of the oceans. Wiley-Liss Inc, New York, p 85-120

Fuchs BM, Glöckner FO, Wulf J, Amann R (2000a) Unlabeled helper oligonucleotides increase the in situ accessibility to 16S rRNA of fluorescently labeled oligonucleotide probes. Appl Environ Microbiol 66:3603-3607

Fuchs BM, Zubkov MV, Sahm K, Burkill PH, Amann R (2000b) Changes in community composition during dilution cultures of marine bacterioplankton as assessed by flow cytometric and molecular biological techniques. Environ Microbiol 2:191-202

Garcon VC, Oschlies A, Doney SC, McGillicuddy D, Waniek $\mathrm{J}$ (2001) The role of mesoscale variability on plankton dynamics in the North Atlantic. Deep-Sea Res II 48: $2199-2226$

Giovannoni SJ, Rappe M (2000) Evolution, diversity, and molecular ecology of marine prokaryotes. In: Kirchman D (ed) Microbial ecology of the oceans. Wiley-Liss Inc, New York, p 47-84

Glockner FO, Amann R, Alfreider A, Pernthaler J, Psenner R, Trebesius K, Schleifer KH (1996) An in situ hybridization protocol for detection and identification of planktonic bacteria. Syst Appl Microbiol 19:403-406

Gonzalez JM, Simo R, Massana R, Covert JS, Casamayor EO, Pedros-Alio C, Moran MA (2000) Bacterial community structure associated with a dimethylsulfoniopropionateproducing North Atlantic algal bloom. Appl Environ Microbiol 66: 4237-4246

Gordon DA, Giovannoni SJ (1996) Detection of stratified microbial populations related to Chlorobium and Fibrobacter species in the Atlantic and Pacific Oceans. Appl Environ Microbiol 62:1171-1177

Karrasch B, Hoppe HG, Ullrich S, Podewski S (1996) The role of mesoscale hydrography on microbial dynamics in the northeast Atlantic: Results of a spring bloom experiment. J Mar Res 54:99-122

Kerkhof LJ, Voytek MA, Sherrell RM, Millie D, Schofield O (1999) Variability in bacterial community structure during upwelling in the coastal ocean. Hydrobiologia 401: 139-148

Le Groupe Tourbillon (1983) The Tourbillon experiment - a study of a mesoscale eddy in the Eastern North Atlantic. Deep-Sea Res I 30:475-511

Lehman JT, Scavia D (1982) Microscale patchiness of nutrients in plankton communities. Science 216:729-730

Long RA, Azam F (2001) Microscale patchiness of bacterioplankton assemblage richness in seawater. Aquat Microb Ecol 26:103-113

Manz W, Amann R, Ludwig W, Vancanneyt M, Schleifer KH (1996) Application of a suite of 16S rRNA-specific oligonucleotide probes designed to investigate bacteria of the phylum Cytophaga-Flavobacter-Bacteroides in the natural environment. Microbiology 142:1097-1106

Marie D, Partensky F, Jacquet S, Vaulot D (1997) Enumeration and cell cycle analysis of natural populations of marine picoplankton by flow cytometry using the nucleic acid stain SYBR Green I. Appl Environ Microbiol 63: 186-193

Mitchell JG, Fuhrman JA (1989) Centimeter scale vertical heterogeneity in bacteria and chlorophyll-a. Mar Ecol Prog Ser 54:141-148

Mitchell JG, Okubo A, Fuhrman JA (1985) Microzones surrounding phytoplankton form the basis for a stratified marine microbial ecosystem. Nature 316:58-59

Muller-Niklas G, Agis M, Herndl GJ (1996) Microscale distribution of bacterioplankton in relation to phytoplankton: results from 100-nl samples. Limnol Oceanogr 41: $1577-1582$

Mullins TD, Britschgi TB, Krest RL, Giovannoni SJ (1995) Genetic comparisons reveal the same unknown bacterial lineages in Atlantic and Pacific bacterioplankton communities. Limnol Oceanogr 40:148-158

Pomeroy LR (1974) The ocean's foodweb: a changing paradigm. Bioscience 24:499-504

Riemann L, Steward GF, Fandino LB, Campbell L, Landry MR, Azam F (1999) Bacterial community composition during two consecutive NE Monsoon periods in the Arabian Sea studied by denaturing gradient gel electrophoresis (DGGE) of rRNA genes. Deep-Sea Res II 46:1791-1811

Seymour JR, Mitchell JG, Pearson L, Waters RL (2000) Heterogeneity in bacterioplankton abundance from 4.5 millimetre resolution sampling. Aquat Microb Ecol 22: 143-153

Shanks AL, Trent JD (1979) Marine snow: microscale nutrient patches. Limnol Oceanogr 24:850-854

Simon M, Azam F (1989) Protein-content and protein-synthesis rates of planktonic marine-bacteria. Mar Ecol Prog Ser 51:201-213 
Simon M, Glockner FO, Amann R (1999) Different community structure and temperature optima of heterotrophic picoplankton in various regions of the Southern Ocean. Aquat Microb Ecol 18:275-284

Tarran GA, Zubkov MV, Sleigh MA, Burkill PH, Yallop M (2001) Microbial community structure and standing stocks in the NE Atlantic in June and July of 1996. Deep-Sea Res II 48:963-985

West NJ, Schonhuber WA, Fuller NJ, Amann RI, Rippka R, Post AF, Scanlan DJ (2001) Closely related Prochlorococcus genotypes show remarkably different depth distributions in two oceanic regions as revealed by in situ hybridization using 16S rRNA-targeted oligonucleotides. Microbiology 147:1731-1744

Woese CR (1987) Bacterial evolution. Microbiol Rev 51: 221-271

Zubkov MV, Fuchs BM, Eilers H, Burkill PH, Amann R (1999) Determination of total protein content of bacterial cells by

Editorial responsibility: William Li,

Dartmouth, Nova Scotia, USA
SYPRO staining and flow cytometry. Appl Environ Microbiol 65:3251-3257

Zubkov MV, Sleigh MA, Burkill PH, Leakey RJG (2000a) Bacterial growth and grazing loss in contrasting areas of North and South Atlantic. J Plankton Res 22:685-711

Zubkov MV, Sleigh MA, Burkill PH, Leakey RJG (2000b) Picoplankton community structure on the Atlantic Meridional Transect: a comparison between seasons. Prog Oceanogr 45:369-386

Zubkov MV, Fuchs BM, Archer SD, Kiene RP, Amann R, Burkill PH (2001a) Linking the composition of bacterioplankton to rapid turnover of dissolved dimethylsulphoniopropionate in an algal bloom in the North Sea. Environ Microbiol 3:304-311

Zubkov MV, Fuchs BM, Burkill PH, Amann R (2001b) Comparison of cellular and biomass specific activities of dominant bacterioplankton groups in stratified waters of the Celtic Sea. Appl Environ Microbiol 67:5210-5218

Submitted: March 27, 2002; Accepted: July 9, 2002

Proofs received from author(s): September 6, 2002 